\title{
KOMUNIKASI GENDER DAN HUBUNGANNYA DENGAN KEPUASAN KERJA KARYAWAN (Gender Communication Related Employees Job Satisfaction)
}

\author{
Putri Asih Sulistiyo $^{1}$, Aida Vitayala Hubeis ${ }^{2}$, Krishnarini Matindas ${ }^{3}$ \\ ${ }^{1}$ Peneliti muda Pusat Kajian Gender dan Anak (PKGA) LPPM IPB \\ ${ }^{2}$ Staff pengajar Program Studi Komunikasi Pembangunan Pertanian dan Perdesaan SPs IPB \\ ${ }^{3}$ Staff pengajar Program Studi Komunikasi Pembangunan Pertanian dan Perdesaan SPs IPB \\ e-mail: putriasihsulistiyo@gmail.com
}

Naskah diterima: 27 Januari 2016; Direvisi: 20 April 2016; Disetujui: 01 Juni 2016

\begin{abstract}
Harding and Hills's standpoint theory said that human perspectives are shaped by their social and political experiences. Gender is a social construction that acquired through interaction and changes over times. Based on that theory, this study used to analyze are the rapid increased of woman labour, gender equity movement in economic development, may affect the the traditional view about how women and men should act and communicate, and established the new meaning of masculinity and feminity in workplace area. The conclusion showed that gender inequity still exist toward women. Women's job position and the level of gender communication based on dimensional stereotype, discrimination, subordination, and sexual harassment are worse than men, but yet women showed no complains and reported the same level of job satisfaction compared men.
\end{abstract}

Keywords: gender, communication, job satisfaction

\section{PENDAHULUAN}

Individu dalam perusahaan terdiri dari laki-laki dan perempuan. Seiring waktu, perempuan mulai menjadi pelaku dalam ekonomi produktif. Berdasarkan statistik ILO pada Tahun 2010 diketahui bahwa terdapat 22,1 persen kesenjangan antara upah laki-laki dan perempuan yang melakukan pekerjaan tetap, turun 3,3 persen sejak 2001. Selain itu, terdapat 50,6 persen kesenjangan antara upah laki-laki dan perempuan yang melakukan pekerjaan harian (turun 1,5 persen sejak 2001), dan dalam politik terdapat 20,1 persen anggota dewan pejabat senior dan manajer perusahaan dari kalangan perempuan (naik 4,3 persen sejak 2007).

Berbagai upaya pembangunan dilakukan untuk menciptakan keadilan gender, mengakhiri dominasi laki-laki dan meningkatkan partisipasi dan eksistensi perempuan dalam dunia kerja. Upaya ini tercermin dari adanya upaya peningkatan kontribusi perempuan sebagai pekerja upahan di sektor nonpertanian sebagai salah satu indikator Millenium Development Goals (MDGS) 2015 dan juga peningkatan kesetaraan gender dalam Sustainable Development Goals (SDGs) 2030.

Salah satu pemicu munculnya ketidakadilan gender pada perempuan adalah melekatnya karakter maskulin pada lingkungan kerja sesuai dengan melekatnya peran produktif pada lakilaki (Wood 2001). Kerja produktif khususnya pada pabrik dan perusahaan memiliki level kompetisi yang tinggi, tekanan kerja yang berat dan pengawasan yang ketat dirasakan berat bagi perempuan karena selama 
ini perempuan tidak mendapatkan sosialisasi budaya kerja, khususnya dari keluarga (Pujisari 2010).

Berdasarkan standpoint theory, masalah maskulinitas dan feminitas merupakan refleksi dari komunikasi, baik verbal maupun non verbal. Bahasa berperan dalam membentuk persepsi dan kesepakatan bersama tentang peran perempuan dan lakilaki yang sesuai dengan nilai dan perspektif budaya (Wood 2001).

Gender sebagai bentukan budaya, maknanya dapat berubah dari waktu ke waktu. Kontribusi perempuan diharapkan berperan dalam upaya mendorong kesetaraan gender dan pemberdayaan perempuan (Venny 2010). Sejalan dengan hal tersebut dan adanya upaya pengarusutamaan gender dalam pembangunan. Penelitian ini bermaksud untuk menganalisis kesetaraan gender di tempat kerja melalui identifikasi komunikasi berprespektif gender dan mengaitkannya dengan kepuasan kerja sebagai salah satu tolak ukur kesejahteraan subjektif karyawan. Kepuasan kerja merupakan ukuran penilaian seseorang terhadap kondisi kerja dan hubungannya dengan pemenuhan harapan, kebutuhan serta keinginan seseorang (Celik 2011).

Penelitian dilakukan di Yogyakarta yang memiliki kekhasan feodalisme dan modernisasi, serta mulai diajukannya perempuan sebagai pimpinan daerah. Kultur budaya yang dimiliki oleh Yogyakarta sebagai lokasi penelitian diharapkan bisa mewarnai hasil penelitian gender dalam lingkup industri yang lebih banyak dilakukan di wilayah dengan latar bekang budaya modern.

\section{MASALAH PENELITIAN}

Sektor ekonomi produktif kini semakin terbuka bagi perempuan. Peningkatan jumlah perempuan dalam sektor produktif non pertanian menjadi agenda pembangunan untuk mewujudkan egaliterisme gender. Hasil telaah penelitian sebelumnya menunjukkan bahwa dalam dunia kerja masih terdapat bentuk ketidakadilan gender berupa stereotipi (Wood 2001), diskriminasi (Gil-Gonzales et.al 2013, Turturean et.al 2013, Popa dan Bucur 2014), marginalisasi (Simantaw 2001), subordinasi (Maume 2011), dan kekerasan seksual (Guay et.al 2014) di lingkungan kerja baik yang disampaikan secara verbal maupun non verbal.

Masalah dalam penelitian ini adalah, pertama, seperti apa gambaran komunikasi gender baik secara verbal maupun non verbal seiring adanya peningkatan partisipasi perempuan dalam sektor produktif? Kedua, apakah terdapat karakteristik individu tertentu yang berhubungan dengan komunikasi gender yang diterima oleh seorang karyawan? Selanjutnya, jika terjadi bentuk-bentuk ketidakadilan gender pada karyawan baik laki-laki maupun perempuan, apakah hal tersebut akan berhubungan dengan kesejahteraan subjektifnya, atau diterima sebagai konsekuensi karena jenis kelamin yang melekat padanya?

Secara khusus, tujuan yang ingin dicapai dalam penelitian ini adalah:

1. Mendeskripsikan bentuk komunikasi gender, karakteristik individu, dan kepuasan kerja.

2. Menguji hubungan antara komunikasi gender dengan karakteristik individu karyawan.

3. Menguji hubungan antara komunikasi gender dengan kepuasan kerja karyawan. 


\section{KERANGKA BERPIKIR}

Sesuai dengan standpoint theory, gender merupakan bentukan kultural yang disosialisasikan dan dipahami oleh individu melalui simbol-simbol verbal maupun non verbal. Kesepakatan makna gender secara komunal dan turun menurun berdasarkan budaya di lokasi penelitian membuat komunikasi gender dalam seluruh pola interaksi masyarakat, termasuk dalam institusi kerja tidak lepas kaitannya dari stereotipi, diskriminasi, marginalisasi, subordinasi dan kekerasan seksual yang mengarah pada salah satu jenis kelamin. Penelitian dilakukan untuk mengetahui komunikasi gender yang terjadi antar jenis kelamin dan dikaitkan dengan peubah-peubah yang berada di tempat kerja.

Lingkungan kerja terdiri dari beragam individu yang memiliki ragam karakteristik. Karakteristik individu di tempat kerja terdiri dari usia, tingkat pendapatan, tingkat pendidikan, status pernikahan, anggota keluarga, lama bekerja dan etnis. Masing-masing karakter ini dipertimbangkan akan berhubungan dengan komunikasi gender. Hal ini sejalan dengan komunikasi gender yang merupakan produk kultural dan dipersepsikan secara individu dan disepakati bersama.

Komunikasi sebagai salah satu faktor lingkungan bersama dengan karakteristik individu merupakan dua peubah yang secara teoritis digunakan untuk mengkaji kepuasan kerja. Kepuasan kerja merupakan salah satu indikator kesejahteraan subjektif yang juga dapat menggambarkan motivasi,

\section{$X_{1}$ Komunikasi Gender}

Isu-isu gender:

$\mathrm{X}_{1.1}$ Stereotipi

$\mathrm{X}_{1.2}$ Diskriminasi

$\mathrm{X}_{1.3}$ Marginalisasi

$\mathrm{X}_{1.4}$ Subordinasi

$\mathrm{X}_{1.5}$ Kekerasan seksual harapan, kebahagiaan dan kepuasan seorang individu terhadap pekerjaan yang dilakukannya. Implikasi kepuasan kerja diantaranya adalah kinerja, tingkat ketidakhadiran dan berpotensi memunculkan atau meredam keinginan berpindah individu dari pekerjaannya. Menguji hubungan antara komunikasi gender dan kepuasan kerja dilakukan untuk melihat sejauh mana harapan perempuan dan laki-laki mengenai pekerjaanya dan sejauh mana dampak isu-isu gender di dunia kerja terhadap kesejahteraan subjektif karyawan baik perempuan maupun laki-laki. Kajian ini masih dilakukan oleh banyak peneliti karena sampai sekarang belum ada kesepakatan ilmiah diantara peneliti terkait hubungan antara isu-isu gender dengan kepuasan kerja.

Ketiga peubah ini di kaji secara deskriptif dan inferensia untuk memperoleh gambaran masingmasing ragam dari peubah dan menguji kaitannya dengan perlakuan komunikasi gender terhadap karyawan. Kerangka berpikir penelitian ini digambarkan pada Gambar 1.

$$
\begin{aligned}
& \quad \mathbf{X}_{2} \text { Karakteristik Individu } \\
& \mathrm{X}_{2.1} \text { Usia } \\
& \mathrm{X}_{2.2} \text { Pendapatan } \\
& \mathrm{X}_{2.3} \text { Pendidikan } \\
& \mathrm{X}_{2.4} \text { Status pernikahan } \\
& \mathrm{X}_{2.5} \text { Lama Bekerja }
\end{aligned}
$$




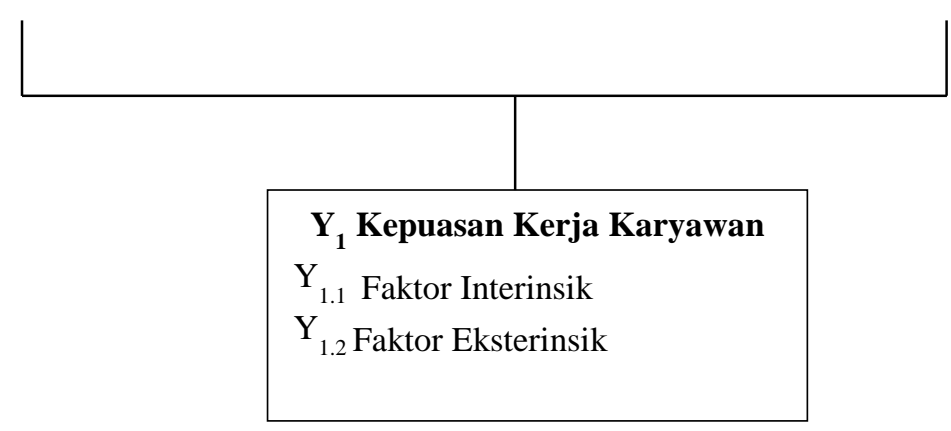

Gambar 1. Kerangka pemikiran komunikasi dan hubungannya dengan kepuasan kerja karyawan perspektif gender

Berdasarkan kerangka pikir di atas, hipotesis yang diuji dalam penelitian ini adalah 1) komunikasi gender memiliki hubungan nyata dengan karakteristik individu, dan 2) komunikasi gender memiliki hubungan nyata dengan kepuasan kerja karyawan.

\section{METODE PENELITIAN}

Penelitian dilaksanakan pada bulan Juni-Agustus 2105 di salah satu agroindustri terbesar Yogyakarta yang telah berdiri lebih dari 60 tahun. Penelitian menggunakan pendekatan kuantitatif melalui metode survei deskriptif korelasional. Jumlah sampel sebanyak 70 orang dari total karyawan sebanyak 361 orang, pengambilan sampel menggunakan proportionate stratified random sampling serta didukung dengan data kualitatif melalui wawancara dengan informan. Nilai validitas terendah untuk peubah komunikasi gender adalah 0,522 dan tertinggi adalah 0,887 . Sedangkan nilai validitas untuk peubah kepuasan kerja berkisar antara 0,500 sampai dengan 0.866 . Hasil uji reliabilitas menggunakan Alpha Cronbach untuk peubah komunikasi gender adalah 0.865 sedangkan untuk peubah kepuasan kerja sebesar 0.976. Analisis data menggunakan uji chi-square untuk menguji peubah nominal dan uji korelasi rank Spearman untuk uji hubungan pada peubah ordinal.

\section{HASIL DAN PEMBAHASAN}

\section{Deskripsi Lokasi Penelitian}

Penelitian ini dilakukan di Daerah Istimewa Yogyakarta yang memiliki jumlah perempuan lebih banyak dari laki-laki, dengan rasio jenis kelamin sebesar 97,69. Terdapat 98 penduduk laki-laki dari 100 penduduk perempuan (BPS 2014).

Berdasarkan survey Sakernas pada Februari 2014, pekerjaan utama sebagian besar penduduk Yogyakarta adalah menjadi buruh/karyawan $(41,81 \%)$. Terdapat 331 perusahaan yang terdiri dari industri besar dan 
sedang di Yogyakarta. Kesempatan kerja di Provinsi DI. Yogyakarta termasuk dalam kategori rendah, khususnya untuk angkatan kerja terdidik. Komposisi penganggur di DI.Yogyakarta di dominasi oleh penganggur terdidik, penganggur dengan tingkat pendidikan SMA sederajat sebanyak 55,23\%, tingkat pendidikan Universitas sebanyak $26,17 \%$, penganggur dengan tingkat pendidikan SMP dan tingkatan lebih rendah dibawahnya sebanyak 18,55\%. (BPS 2014).

Tingkat partisipasi angkatan kerja (TPAK) laki-laki berada pada kisaran angka 77-82 persen, sedangkan TPAK perempuan berada pada kisaran angka 57-67 persen. Nilai ini menunjukkan bahwa keterlibatan penduduk laki-laki dalam aktivitas ekonomi produktif lebih tinggi dibandingkan penduduk perempuan (BPS 2014). Dalam narasinya, BPS (2014) juga menyimpulkan TPAK Yogyakarta mampu mendeskripsikan pandangan masyarakat Yogyakarta tentang nafkah, bahwa kewajiban pencarian nafkah merupakan tanggung jawab laki-laki. Meskipun perempuan memiliki TPAK yang lebih rendah dari laki-laki, namun statistik menunjukkan bahwa jumlah perempuan pencari kerja yang terserap dalam dunia kerja semakin meningkat.

\section{Gender di Yogyakarta dan di Lokasi Penelitian}

Gender diartikan sebagai suatu konsep yang merujuk pada sistem peranan hubungan antara lakilaki dan perempuan yang bukan ditentukan oleh pembedaan biologis, akan tetapi oleh lingkungan sosialbudaya, politik dan ekonomis (Hubeis AV 2010). Gender dalam konteks komunikasi menggambarkan hubungan sosial dan personal antara laki-laki dan perempuan dan demikian pula dengan konsep feminin dan maskulin (Hubeis AV 2010).

Menurut Wood (2001) bahasa secara verbal membentuk konsep perempuan, laki-laki, dan hubungan antara laki-laki dan perempuan. Bahasa verbal membentuk persepsi manusia dalam memaknai suatu hal. Simbol-simbol nonverbal tidak memaknai dirinya sendiri, namun dimaknai secara verbal oleh individu atau kelompok. Makna verbal tersebut yang akan menjadi representasi sebuah simbol.

Berdasar standpoint theory dikatakan bahwa bagaimana seseorang dibesarkan dalam suatu budaya akan memengaruhi bentuk kehidupan. Dalam dunia ini terdapat banyak hirarki, baik gender, etnis, maupun kelas yang memengaruhi kehidupan manusia. Perempuan sebagai kaum minoritas dalam hierarki patriarki akan memiliki pandangan yang berbeda dengan lakilaki, sehingga kita harus memahami suatu peristiwa dalam dua cara pandang yang berbeda, cara pandang laki-laki dan cara pandang perempuan. Cara pandang ini memengaruhi komunikasi serta perilaku perempuan dalam berinteraksi dan menjalani kehidupan (Wood 2001).

Wood (2001) menerangkan bahwa bahasa memaknai laki-laki dan perempuan secara berbeda. Perempuan dimaknai melalui penampilannya dan hubungannya dengan orang lain. Saat perempuan memiliki capaian dalam dunia profesional, maka yang diangkat media bukan hanya profil usahanya dan kerja kerasnya, melainkan penampilanya. Sedangkan laki-laki 
dimaknai melalui aktivitasnya, capaian yang dilakukannya atau posisinya. Perbedaan cara pemaknaan laki-laki dan perempuan merelfeksikan pandangan umum masyarakat.

Makna gender dan perempuan di Yogyakarta terus berevolusi sesuai dengan perkembangan sosial dan budaya di Yogyakarta. Perempuan Jawa sampai akhir abad ke 15 di definisikan berdasarkan peradaban hindu, terstratifikasi dalam dua tahapan, pertama perempuan dalam hirarkhi yang lebih rendah dari lakilaki, dan kedua perempuan terstatifikasi dalam lapisan sosialnya. Perubahan sosial mulai muncul beriringan dengan berdirinya Muhammadiyah. Munculnya Muhammadiyah dapat dikatakan sebagai awal pembebasan dari adat Jawa lama yang secara tegas mensubordinasi perempuan, pada masa ini perempuan sudah diperbolehkan untuk bersekolah. Selanjutnya, pada rezim orde baru perempuan jawa sudah diperkenankan untuk masuk kedalam wilayah publik, salah satunya adalah ranah politik (Dewi 2012).

Selain melihat dalam sudut pandang masyarakat, kesadaran gender sebuah organisasi dapat dilihat dari sudut pandang organisasi itu sendiri. Menurut Ruthenfold (2011) kesadaran gender dapat diabstraksi dengan melihat seberapa banyak jumlah perempuan dalam organisasi dan dimana kedudukannya, apakah perempuan dihormati dan dihargai sebagai tenaga kerja serta sampai pada fase mana kesadaran gender yang dimiliki individu karyawan.

Berdasarkan hasil wawancara, diketahui bahwa secara kuantitatif jumlah karyawan perempuan di perusahaan ini meningkat dari beberapa tahun sebelumnya. Posisi sebagian besar perempuan dalam perusahaan berada pada bagian sumberdaya manusia, sekretariat, dan akuntansi. Perempuan yang bekerja pada bidang lain seperti bagian tanaman, instalasi, pabrikasi, menempati posisi administrasi pada bagian tersebut, sedangkan pada bagian tebangan tidak terdapat karyawan perempuan.

Perempuan dan laki-laki masih dinilai sebagai dua pribadi yang memiliki kapasitas individu berbeda. Perusahaan masih menunjukkan adanya segregasi pekerjaan antara laki-laki dan perempuan. perusahaan membuka kesempatan pada laki-laki maupun perempuan yang memiliki kapasitas untuk bekerja di bagian manapun dalam perusahaan, namun tetap masih terindikasi halangan semu bagi perempuan.

"Sebetulnya dari awal
sampai akhir tidak ada
mengkhususkan laki-laki
atau perempuan (mulai
dalam penerimaan) tetapi
melihat tempat kerja dan
kondisinya, kalau
katakanlah kerja pabrik
dengan kapasitas kerja yang
seperti itu, apa kira-kira
mampu perempuan?
Akhirnya pada
mengundurkan diri, dulu
ada yang bagian tanaman
ada yang mendaftar,
akhirnya baru pengenalan
sudah mengundurkan diri,
karena jangkauan kita 9
kabupaten, walaupun tidak
tiap hari kunjungan, tapi
kadang-kadang sehari bisa
mengunjungi dua kabupaten
yang berbeda". (Bapak T.)


ISSN 1693-3699

Pernyataan tidak keberatan dengan keberadaan perempuan jika perempuan tersebut mampu menjalankan pekerjaan seperti yang laki-laki kerjakan dapat diklasifikasikan sebagai pemahaman buta gender. Pemahaman gender ini dapat menghalangi perempuan untuk bergabung dan berkembang di perusahaan. Perempuan di hakimi sebagai individu yang tidak kompeten dibidang lain selain dibidangnya, tetapi laki-laki dapat diterima dibidang kerja yang identik dengan perempuan seperti administrasi, SDM, dan keuangan tanpa harus diberi pesan untuk dapat bekerja teliti, rapi, rajin, seperti perempuan.

\section{Identifikasi Komunikasi Gender}

Isu komunikasi berkontribusi dalam menciptakan halangan bagi kemajuan perempuan dalam organisasi, atau setidaknya menciptakan beragam kesalahpahaman tentang laki-laki dan perempuan dalam dunia kerja (Barrett dan Davidson 2006). Frekuensi komunikasi gender dalam penelitian ini diharapkan dapat menunjukkan sejauhmana konstruksi gender yang berada pada ranah kognitif seseorang diterjemahkan kedalam bahasa verbal maupun non verbal kepada karyawan lainnya melalui interaksi sosial yang dilakukan di perusahaan. Tabel 1 menunjukkan komunikasi gender yang diterima oleh responden.

Tabel 1 Sebaran frekuensi dan persentase responden berdasarkan komunikasi gender menurut jenis kelamin

\begin{tabular}{llrrr}
\hline \multirow{2}{*}{$\begin{array}{l}\text { Komunikasi } \\
\text { Gender }\end{array}$} & \multirow{2}{*}{ Uraian } & \multicolumn{2}{c}{ Laki-laki } & P \\
\cline { 3 - 5 } Stereotipi & Rendah & 6 & 12 & \\
& Sedang & $\mathbf{3 6}$ & $\mathbf{7 2}$ & $\mathbf{1 5}$ \\
Total & Tinggi & 8 & 16 & \\
& & 50 & 100 & 20 \\
Diskriminasi & Rendah & 10 & 20 & \\
& Sedang & $\mathbf{3 1}$ & $\mathbf{6 2}$ & $\mathbf{1 7}$ \\
Total & Tinggi & 9 & 18 & \\
& & 50 & 100 & 20
\end{tabular}

Jurnal Komunikasi Pembangunan Juli 2016 Vol 14, No 2

\begin{tabular}{llrrrr}
\hline \multirow{3}{*}{ Marginalisasi } & Rendah & $\mathbf{4 0}$ & $\mathbf{8 0}$ & $\mathbf{1 5}$ & $\mathbf{7 5}$ \\
& Sedang & 10 & 20 & 5 & 25 \\
Total & Tinggi & 0 & 0 & 0 & 0 \\
\hline \multirow{3}{*}{ Subordinasi } & & 50 & 100 & 20 & 100 \\
& Rendah & 23 & 46 & 4 & 20 \\
Total & Sedang & $\mathbf{2 5}$ & $\mathbf{5 0}$ & $\mathbf{1 2}$ & $\mathbf{6 0}$ \\
& Tinggi & 2 & 4 & 4 & 20 \\
Kekerasan & Rendah & 50 & 100 & 20 & 100 \\
Seksual & Sedang & 8 & 16 & 4 & 20 \\
Total & Tinggi & 2 & 4 & 5 & 25 \\
\hline
\end{tabular}

Sebagai upaya menguatkan analisis deskriptif, dilakukan uji chisquare yang bertujuan untuk membandingkan penerimaan perilaku komunikasi antara karyawan laki-laki dan karyawan perempuan dengan melihat keterkaitan antara komunikasi gender dengan jenis kelamin. Proporsi yang berbeda menunjukkan bahwa adanya keterkaitan antara jenis kelamin dengan intensitas penerimaan komukasi gender. Proporsi sama menunjukkan proporsi yang seharusnya antara laki-laki dan perempuan dalam penerimaan komunikasi gender, sehingga penerimaan komunikasi gender dapat dikatakan sama (proporsional) antara laki-laki dan perempuan.

Tabel 2 Hubungan komunikasi gender dengan jenis kelamin

\begin{tabular}{lccc}
\hline Komunikasi Gender & $\mathrm{x}^{\mathbf{2}}$ hitung & Keterangan & $\begin{array}{c}\text { Koefisien } \\
\text { korelasi }\end{array}$ \\
\hline Stereotipi Perempuan & 26,926 & Proporsi berbeda & $\mathbf{0 , 0 0 0}$ \\
Stereotipi Laki-laki & 11,075 & Proporsi berbeda & $\mathbf{0 , 0 0 4}^{*}$ \\
Diskriminasi & 5,177 & Proporsi berbeda & $\mathbf{0 , 0 2 0}^{*}$ \\
Marginalisasi & 0,212 & Proporsi sama & 0,645 \\
Subordinasi & 7,041 & Proporsi berbeda & $\mathbf{0 , 0 3 0}^{*}$ \\
Kekerasan Seksual & 7,659 & Proporsi berbeda & $\mathbf{0 , 0 2 2}^{*}$ \\
\hline \hline Keterangan : $*$ Signifikansi korelasi pada nilai $\alpha=$ & \\
$0,05, x^{2}$ kritis $=3,841$ & & \\
& &
\end{tabular}


Hasil uji memperlihatkan peubah-peubah komunikasi gender yang berhubungan dengan jenis kelamin adalah stereotipi, diskriminasi, subordinasi dan kekerasan seksual, sedangkan peubah komunikasi gender marginalisasi tidak berhubungan dengan jenis kelamin.

Pertama, stereotipi, berdasarkan data deskriptif diketahui bahwa pada intensitas komunikasi stereotipi sedang dan rendah di dominasi oleh karyawan perempuan, sedangkan komunikasi stereotipi dengan intensitas tinggi lebih banyak diterima oleh laki-laki. Sebagian besar karyawan baik laki-laki maupun perempuan mendapatkan komunikasi stereotipi dalam intensitas sedang. Stereotipi dalam ruang profesional di perusahaan membuat perempuan hanya bisa menduduki pekerjaan sekunder, dan laki-laki harus mampu menjalankan pekerjaan yang membutuhkan kemampuan fisik. Hal ini tentunya merugikan baik untuk laki-laki maupun untuk perempuan.

Kedua, diskriminasi terdapat perbedaan proporsi penerimaan perilaku komunikasi diskriminasi antara karyawan perempuan dan karyawan laki-laki di PT Madubaru. Meskipun kebijakan perusahaan sudah membuka peluang bagi perempuan, namun masih terlihat fenomena glass ceiling di perusahaan. Pada PT Madubaru perempuan tidak dapat menembus level eksekutif perusahaan, kecuali pada bidang sumberdaya manusia. Pada bagian lain, perempuan hanya berada pada level staff dikarenakan kebijakan yang tidak tertulis, yaitu karena berjenis kelamin perempuan.

Selanjutnya marginalisasi, merupakan bentuk peminggiran eksistensi perempuan dalam dunia kerja. Berdasarkan hasil penelitian, diketahui bahwa marginalisasi tidak berhubungan dengan jenis kelamin. Baik laki-laki dan perempuan mendapatkan perilaku komunikasi marginalisasi dalam proporsi yang sama. Tidak terdapat marginaliasi dalam bentuk ketimpangan ekonomi, fasilitas, standar gaji yang diterima laki-laki dan perempuan di PT Madubaru. Keseluruhannya sudah diatur dan dijalankan sesuai dengan kesepakatan bersama yang tertuang dalam PKB (Perjanjian Kinerja Bersama). Meskipun demikian, bentuk-bentuk marginalisasi kepada perempuan dan laki-laki tetap dapat teridentifikasi. Segregasi pekerjaan merupakan salah satu bentuk marginalisasi pada perempuan, dan kenaikan pangkat merupakan salah satu bentuk marginalisasi yang dirasakan oleh karyawan laki-laki dengan masa pengabdian yang lama namun memiliki tingkat pendidikan yang lebih rendah.

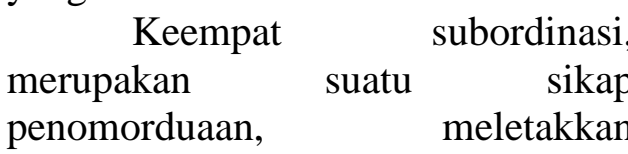
seseorang pada posisi bawah atau posisi inferior karena jenis kelamin yang melekat pada dirinya. Karyawan perempuan di dalam perusahaan lebih diarahkan sesuai dengan sifat yang cocok dengan perempuan, dalam konteks pabrik pekerjaan yang sesuai dengan stereotipi perempuan hanyalah bagian administrasi dan keuangan, sedangkan laki-laki memiliki pilihan yang lebih beragam. Subordinasi lain juga terlihat dari susunan managemen perusahaan, keseluruhan struktur pimpinan cenderung di dominasi oleh laki-laki, hanya ada satu perempuan yang menjadi karyawan pimpinan dan diposisikan sebagai kepala bidang SDM. Perempuan jarang menempati 
posisi strategis dalam perusahaan dan memiliki peluang karir yang lebih sempit dibandingkan laki-laki.

Terakhir kekerasan seksual, pada dasarnya tingkat kekerasan yang terjadi didalam lingkungan perusahaan cederung rendah dan dapat dikontrol, tidak pernah terjadi perkelahian secara terbuka antara karyawan dalam perusahaan. Hal ini sesuai dengan data yang didapatkan dari penelitian, bahwa kekerasan fisik berupa pukulan, tamparan, dorongan, dan sebagainya mendapatkan persentase paling rendah dibandingkan bentuk kekerasan lainnya.

Berdasarkan persentase hasil penelitian, kekerasan seksual responden perempuan lebih tinggi dibandingkan responden laki-laki. Perempuan lebih sering diabaikan oleh timnya, dicemarkan nama baiknya (dijadikan objek gosip), merasa tertekan karena kritik terus menerus, dimarahi dengan gebrakan meja/ lemparan kertas/ dipelototi, ditatap sinis, dirayu, disentuh tanpa persetujuan dan mendapatkan sentuhan fisik secara kasar. Satusatunya bentuk komunikasi gender yang lebih sering dialami oleh lakilaki dibanding perempuan adalah diperolehnya ancaman dari rekan kerja atau atasan.

\section{Identifikasi Karakteristik Individu}

Karakteristik individu yang diamati adalah usia, tingkat pendapatan, tingkat pendidikan, status pernikahan dan lama bekerja. Rentang usia responden secara keseluruhan berkisar antara 21- 54 tahun. Sebanyak $70 \%$ responden perempuan berada pada usia muda (21-31 tahun). Sebagian besar responden laki-laki (46\%) berada pada usia 43-54 tahun.
Ragam masa kerja responden dimulai dari 6 bulan sampai masa kerja lebih dari 20 tahun. Sebagian besar responden laki-laki (38\%) berada pada rentang masa kerja lebih dari 20 tahun. Sedangkan responden perempuan sebagian besar $(45 \%)$ bekerja selama 1-3 tahun. Perbandingan lama bekerja pegawai laki-laki dan perempuan dapat menggambarkan usia perusahaan dan karakter maskulin perusahaan. Jumlah perempuan yang bekerja diperusahaan mulai meningkat dalam dekade terakhir. Sebelumnya hampir seluruh pegawai perusahaan merupakan laki-laki.

Jumlah pendapatan karyawan di perusahaan setiap bulannya telah diatur dalam PKB (Perjanjian Kinerja Bersama) yang telah disepakati oleh pimpinan, karyawan, dan serikat pekerja perusahaan. Sebanyak 95\% responden perempuan dan $62 \%$ lakilaki memiliki pedapatan $\mathrm{Rp}$ 1.000 .000 - Rp 2.000.000 per bulan.

Tingkat pendidikan formal menunjukkan kualitas sumber daya manusia. Tingkat pendidikan responden laki-laki sebagian besar (76\%) sampai jenjang pendidikan SMA, hal ini berkaitan juga dengan usia dan lama bekerja. Sedangkan perempuan sebagian besar 50\% berada pada jenjang pendidikan sarjana. Pendidikan yang dimiliki karyawan perempuan perusahaan menunjukkan bahwa sebagian besar perempuan di perusahaan ini merupakan sumberdaya manusia yang kompetitif dan terdidik. Sedangkan untuk status pernikahan, hampir seluruh responden memiliki status menikah, laki-laki sebanyak $92 \%$ dan perempuan sebanyak $70 \%$.

\section{Identifikasi Kepuasan Kerja}


Kepuasan kerja dapat di deskripsikan sebagai perasaan menyenangkan atau emosi positif sebagai hasil evaluasi dari pengalaman kerja seorang karyawan (Celik 2011). Kepuasan kerja mengacu pada tingkat kenyamanan yang didapatkan oleh karyawan dari usahanya di tempat kerja yang sangat berasosiasi dengan organisasi yang
Juli 2016 Vol 14, No 2

baik dan kinerja individual, komitmen, peningkatan produktivitas, ketidakhadiran yang rendah, dan rendahnya keinginan berpindah kerja (Ciarniene 2010). Gambar 2 dan Gambar 3 menggambarkan tingkat kepuasan kerja karyawan baik laki-laki maupun perempuan.

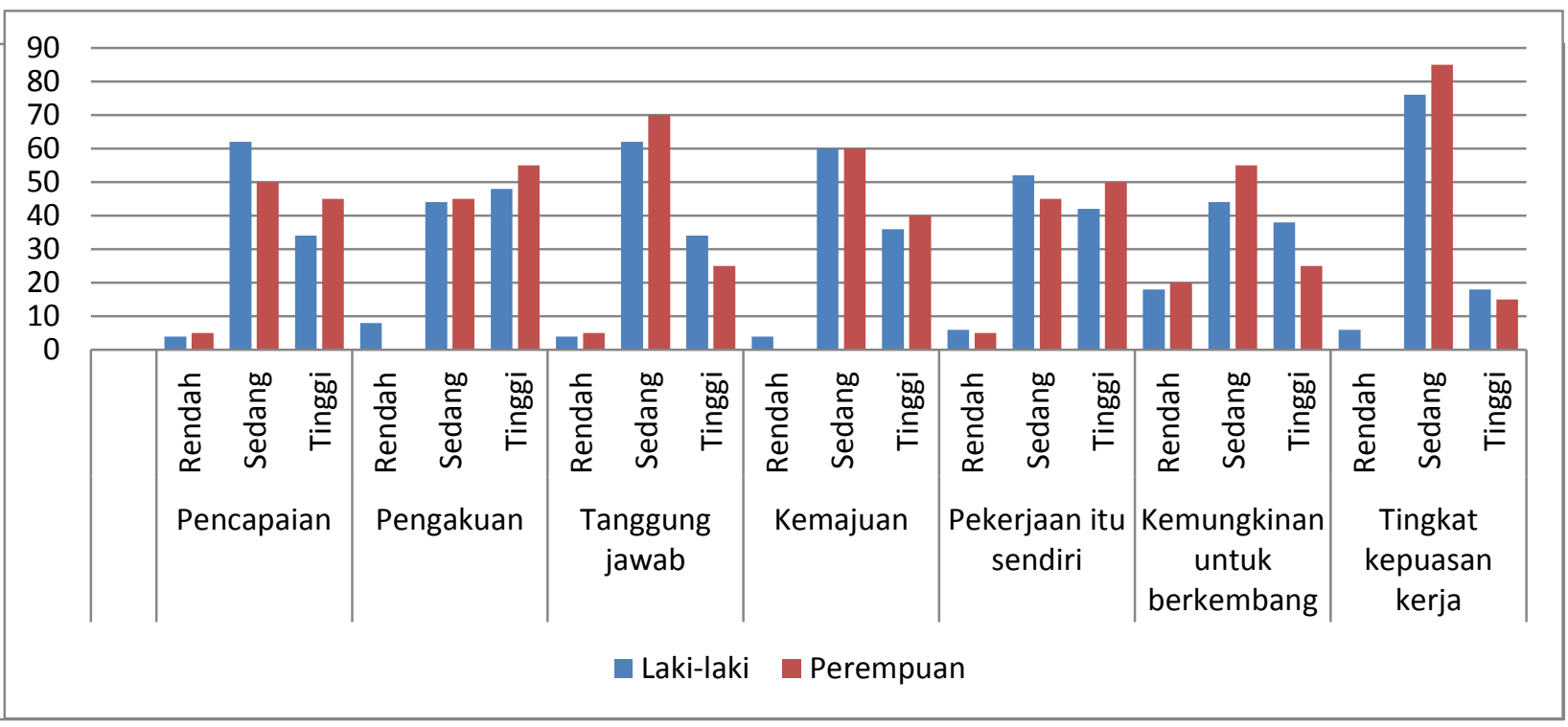

Gambar 2. Persentase penilaian kepuasan kerja internal berdasarkan jenis kelamin

Karyawan perusahaan baik laki-laki maupun perempuan sebagian besar memberikan penilaian sedang pada tiap-tiap indikator kepuasan kerja. Karyawan tidak merasa sangat puas juga tidak merasa sangat tidak puas, penilaiannya hanya pada tingkatan sedang (cukup) saja. Indikator kepuasan kerja yang dinilai mampu memberikan kepuasan kerja tinggi pada karyawan laki-laki hanya indikator pengakuan, penghargaan atau perhatian (48\%), sedangkan
Berdasarkan hasil uji chisquare diketahui bahwa indikator gaji dan kondisi kerja merupakan dua indikator yang memiliki nilai signifikansi $\alpha<0,01$. Hal ini berarti karyawan laki-laki dan perempuan hanya memiliki penilaian berbeda pada dua indikator tersebut. Sesuai dengan uraian sebelumnya, karyawan perempuan lebih merasa puas terhadap kondisi kerja yang mendukung, aspek kondisi kerja yang mendukung adalah kesesuaian

Gambar 3. Persentase penilaian kepuasan kerja eksternal berdasarkan jenis kelamin

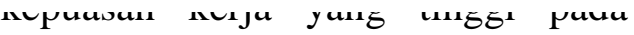
indikator kondisi kerja (65\%), hubungan interpersonal (55\%) dan pekerjaan itu sendiri $(50 \%)$. karyawan. Salah satu aspek kondisi kerja adalah jumlah waktu kerja yang tidak berlebihan, jumlah waktu istirahat yang cukup, kemampuan 
tim, kebersihan dan lingkungan kerja. Karyawan perempuan juga merasa puas dengan kemudahan bergaul sesama rekan kerja dan bahasa santun dalam berkomunikasi. Hal lain yang diberi penilaian tinggi oleh karyawan perempuan adalah pekerjaan itu sendiri. Karyawan perempuan merasa nyaman dengan posisi dan jenis pekerjaan yang sedang dijalani. Pekerjaan yang sedang dijalani dinilai sesuai dengan kemampuan dan minat yang dimiliki oleh karyawan perempuan.

\section{Hubungan Antara Komunikasi Gender dengan Karakteristik Individu}

Hipotesis pertama penelitian ini adalah adanya hubungan antara komunikasi gender dengan karakteristik individu. Penerimaan komunikasi gender yang tinggi mencerminkan adanya ketidakadilan gender yang diterima oleh karyawan.

Berdasarkan hasil uji rank Spearman dapat disimpulkan bahwa komunikasi stereotipi pada laki-laki dan perempuan serta kekerasan gender berhubungan dengan beberapa indikator karakteristik individu. Stereotipi perempuan berhubungan sangat nyata positif dengan tingkat pendidikan dan berhubungan nyata negatif dengan tingkat penghasilan. Stereotipi laki-laki berhubungan sangat nyata negatif dengan tingkat pendidikan dan berhubungan nyata positif dengan usia. Kekerasan gender berhubungan sangat nyata positif dengan tingkat pendidikan dan berhubungan nyata negatif dengan lama bekerja.

Pada responden perempuan terdapat hubungan sangat nyata positif antara stereotipi dengan tingkat pendidikan. Hal ini berarti komunikasi stereotipi semakin sering disampaikan pada karyawan perempuan dengan pendidikan tinggi. Sebagian besar karyawan perempuan yang berpendidikan tinggi merupakan karyawan yang diposisikan pada bagian administrasi, dengan tuntutan kerapihan, ketelitian dan penampilan menarik dalam bekerja.

Tabel 3 Hubungan antara komunikasi gender dengan karakteristik individu

\begin{tabular}{lllrrr}
\hline Komunikasi gender & $\begin{array}{l}\text { Tingkat } \\
\text { Pendidikan }\end{array}$ & Usia & $\begin{array}{c}\text { Status } \\
\text { Perkawinan }\end{array}$ & $\begin{array}{c}\text { Tingkat } \\
\text { Penghasilan }\end{array}$ & Lama Bekerja \\
\hline Stereotipi perempuan & $\mathbf{0 . 3 2 4}^{* *}$ & $-0,114$ & 0,164 & $\mathbf{- 0 . 2 4 2}^{*}$ & $-0,206$ \\
Stereotipi laki-laki & $\mathbf{- 0 . 3 3 5 *}^{* *}$ & $\mathbf{0 . 2 4 8}^{*}$ & $-0,066$ & 0,226 & 0,221 \\
Diskriminasi & $-0,005$ & 0,034 & 0,049 & $-0,041$ & $-0,004$ \\
Marginalisasi & $-0,022$ & 0,068 & $-0,114$ & 0,001 & 0,212 \\
Subordinasi & 0,132 & 0,023 & 0,214 & $-0,012$ & $-0,031$ \\
Kekerasan seksual & $\mathbf{0 . 3 1 7}^{* *}$ & $-0,100$ & $-0,001$ & $-0,225$ & $\mathbf{- 0 . 2 6 1}^{*}$ \\
\hline
\end{tabular}

Keterangan: *Berhubungan nyata $(p$-value $<0,05) ; * *$ Berhubungan sangat nyata $(p$-value $<0,01)$

Pada responden perempuan, stereotipi memiliki hubungan nyata negatif dengan tingkat penghasilan. Berarti perempuan yang lebih sering dilabeli dengan stereotipi adalah peremuan dengan tingkat penghasilan yang lebih rendah. Tingkat penghasilan seorang karyawan di perusahaan ini berkaitan dengan jabatan. Pada karyawan perempuan, komunikasi stereotipi jarang 
disampaikan pada karyawan dengan jabatan yang leih tinggi.

Berkebalikan dengan

responden perempuan, laki-laki yang

lebih sering diperlakukan secara stereotipi adalah laki-laki dengan pendidikan yang lebih rendah. Pada responden laki-laki stereotipi berhubungan sangat nyata negatif dengan tingkat pendidikan yang dimilikinya. Laki-laki dengan pendidikan tinggi dihargai, dihormati, dan dipercaya mampu melakukan tanggung jawab sebagai laki-laki.

Pada laki-laki, stereotipi memiliki hubungan nyata positif dengan usia, nilai signifikansi korelasinya sebesar 0,248. Laki-laki yang memiliki usia lebih matang lebih dibebankan sebagai pencari nafkah utama. Beban ekonomi merupakan tanggung jawab yang harus dipenuhinya sejalan dengan ukuran keluarga yang dimiliki.

Kekerasan gender

berhubungan sangat nyata positif dengan tingkat pendidikan, dengan nilai korelasi 0,294. Semakin tinggi pendidikan seorang karyawan semakin tinggi intensitas komunikasi gender yang diterimanya. Sepuluh dari 19 responden yang memiliki pendidikan sarjana adalah perempuan, selain itu sebanyak $48 \%$ karyawan yang berpendidikan tinggi, baik laki-laki maupun perempuan juga merupakan karyawan berusia muda dengan masa kerja yang rendah dan posisi jabatan yang rendah. Bentuk kekerasan gender yang diterima dengan intensitas lebih tinggi oleh karyawan berpendidikan adalah kekerasan berupa ancaman, pengabaian, gosip, tatapan sinis, rayuan dan sentuhan. Bentuk kekerasan gender tertinggi yang dialami oleh karyawan dengan pendidikan rendah adalah diteriaki, dan di kritik dengan kata kasar.

Kekerasan

gender berhubungan nyata negatif dengan lama bekerja, dengan nilai korelasi 0,261 . Semakin lama seseorang karyawan bekerja di perusahaan, semakin rendah perilaku kekerasan gender yang diterimanya. Kekerasan gender lebih banyak dialami oleh laryawan karyawan-karyawan baru dengan masa kerja yang lebih pendek. Kekerasan gender yang sering dialami oleh karyawan junior adalah diteriaki oleh rekan kerja atau atasan, dicemarkan nama baiknya (dijadikan objek gosip), dimarahi oleh atasan atau rekan kerja dengan gebrakan meja atau lemparan kertas, dan dimarahi dengan kata kasar yang tidak patut.

\section{Hubungan Antara Komunikasi Gender dengan Kepuasan Kerja}

Hipotesis kedua penelitian ini adalah adanya hubungan antara komunikasi gender dengan kepuasan kerja. Penelitian sebelumnya tentang komunikasi dan hubungannya dengan kepuasan kerja menunjukkan hasil yang beragam. Beberapa peneliti (Clark 1997; Bender et.al 2005; Kifle dan Desta 2012; Aydin et.al 2012) menyatakan bahwa perempuan memiliki kepuasan kerja lebih tinggi dari laki-laki. Peneliti lain (Sabharwal dan Corley 2009; Negi 2009) menyimpulkan bahwa perempuan memiliki kepuasan kerja lebih rendah dibanding laki-laki. Sedangkan Gumbang et.al (2010) menyatakan bahwa tidak ada perbedaan tingkat kepuasan kerja antara laki-laki dan perempuan.

Tabel 4 Hubungan antara komunikasi gender dengan kepuasan kerja internal 


\begin{tabular}{|c|c|c|c|c|c|c|c|}
\hline \multirow[b]{2}{*}{ Komunikasi gender } & \multicolumn{7}{|c|}{ Kepuasan Kerja Internal } \\
\hline & Gaji & $\begin{array}{c}\text { Keamanan } \\
\text { Kerja }\end{array}$ & $\begin{array}{c}\text { Kondisi } \\
\text { Kerja }\end{array}$ & Status & $\begin{array}{l}\text { Kebijakan } \\
\text { Perusahaan }\end{array}$ & Pengawasan & $\begin{array}{l}\text { Hubungan } \\
\text { Inter- } \\
\text { personal }\end{array}$ \\
\hline Stereotipi perempuan & $-0,134$ & $-0,049$ & $0.237^{*}$ & $-0,083$ & 0,143 & $-0,051$ & $-0,011$ \\
\hline Stereotipi laki-laki & 0,140 & 0,117 & $-0,125$ & $0.243^{*}$ & $-0,077$ & $-0,044$ & $-0.250^{*}$ \\
\hline Diskriminasi & $-0,124$ & $-0,189$ & $-0,142$ & $-0,091$ & 0,035 & $-0,134$ & $-0,180$ \\
\hline Marginalisasi & 0,024 & 0,063 & 0,087 & $0.251^{*}$ & 0,079 & 0,109 & $-0,001$ \\
\hline Subordinasi & $-0,194$ & $-0,025$ & 0,002 & 0,011 & $-0,057$ & $-0,093$ & $-0,125$ \\
\hline Kekerasan seksual & $-0,028$ & $-0,020$ & $0.409^{* *}$ & $-0,048$ & 0,012 & $-0,224$ & $-0,139$ \\
\hline
\end{tabular}

Keterangan: *Berhubungan nyata $(p$-value $<0,05) ; * *$ Berhubungan sangat nyata $(p$-value $<0,01)$

Berdasarkan hasil uji rank Spearman, pada perempuan stereotipi berhubungan sangat nyata positif dengan kondisi kerja. Karyawan perempuan yang memiliki nilai stereotipi tinggi adalah karyawan administrasi dan informasi yang mendapatkan ruangan di bagian perusahaan, ruangan bersih dan tertata rapi, jam kerja tidak berlebihan, serta mendaptkan waktu istirahat cukup.

Stereotipi pada karyawan lakilaki berhubungan nyata positif dengan status. Status yang dimaksud adalah kepuasan terhadap status kepegawaian yang dimiliki (kontak/tetap/outsourching).

Karyawan laki-laki yang memiliki kepuasan terhadap status adalah karyawan laki-laki yang lebih sering mendapat komentar agar memiliki fisik yang tangguh, kuat, dalam bekerja khususnya pekerjaan berat (tebang, mesin, dll). Stereotipi pada karyawan laki-laki juga memiliki hubungan nyata negatif dengan hubungan interpersonal. Karyawan laki-laki yang memiliki nilai stereotipi tinggi dan memiliki hubungan interpersonal rendah sebagian besar adalah karyawan bagian pabrikasi. Hubungan interpersonal dinilai berdasarkan kepuasan terhadap komunikasi atasan bawahan maupun $\begin{array}{lrr}\text { komunikasi } & \text { antar } & \text { rekan } \\ \text { kerja.Lingkungan } & \text { kerja } & \text { bagian } \\ \text { pabrikasi yang } & \text { lebih } & \text { banyak }\end{array}$ bersentuhan dengan mesin membuat kualitas komunikasi yang dimiliki karyawan bagian tersebut rendah.

Marginalisasi berhubungan nyata positif dengan status. Marginalisasi sendiri diartikan sebagai penyingkiran eksistensi seseorang. Karyawan yang merasa memiliki promosi karir yang rendah serta merasa rentan terkena PHK memiliki kepuasan terhadap status yang lebih rendah dibandingkan karyawan lainnya.

Selanjutnya kekerasan seksual berhubungan sangat nyata positif dengan kondisi kerja. Hal ini menunjukkan adanya kontradiksi. Karyawan yang mendapatkan perlakuan tidak menyenangkan selama bekerja ternyata memiliki kepuasan terhadap kondisi kerja yang tinggi. Indikator jumlah jam kerja dan jumlah waktu istirahat di perusahaan sangat memengaruhi tingginya kepuasan karyawan terhadap kepuasan kondisi kerja, walaupunkaryawan tersebut mendapatkan pengalaman kekerasan seksual dalam pekerjaannya.

Tabel 5 Hubungan antara komunikasi gender dengan kepuasan kerja eksternal

\begin{tabular}{|c|c|c|c|c|c|c|}
\hline \multirow[b]{2}{*}{ Karakteristik Individu } & \multicolumn{6}{|c|}{ Kepuasan Kerja Eksternal } \\
\hline & Pencapaian & Pengakuan & $\begin{array}{c}\text { Tanggung } \\
\text { Jawab }\end{array}$ & Kemajuan & $\begin{array}{l}\text { Pekerjaan } \\
\text { itu sendiri }\end{array}$ & $\begin{array}{l}\text { Keinginan } \\
\text { berkembang }\end{array}$ \\
\hline
\end{tabular}




\begin{tabular}{lrrrrrr}
\hline Stereotipi perempuan & 0,155 & $-0,010$ & 0,085 & $-0,003$ & $-0,070$ & $-0,087$ \\
Stereotipi laki-laki & $-0,094$ & $-0,016$ & 0,131 & $-0,029$ & 0,018 & $-0,034$ \\
Diskriminasi & $-0,081$ & $-0,089$ & $-0,128$ & $-0,033$ & $-0,110$ \\
Marginalisasi & 0,013 & $-0,003$ & 0,071 & 0,048 & $-0,009$ \\
Subordinasi & $-0,023$ & $-0,111$ & 0,031 & 0,022 & $-0,037$ & $-0,123$ \\
Kekerasan seksual & $-0,107$ & $-0,081$ & 0,107 & $-0,157$ & $-0,073$ & $-0,049$ \\
\hline
\end{tabular}

Keterangan: *Berhubungan nyata $(p$-value $<0,05) ; * *$ Berhubungan sangat nyata $(p-v a l u e<0,01)$

Berdasarkan hasil analisis data, diketahui bahwa tidak ada indikator komunikasi gender yang berhubungan nyata dengan indikator kepuasan kerja eksternal, baik kepuasan pencapaian, pengakuan, tanggung jawab, kemajuan, pekerjaan itu sendiri maupun keinginan berkembang.

Hasil analisis hubungan komunikasi gender dan kepuasan kerja menunjukkan bahwa pengalaman negatif di dunia kerja seperti spesialisasi pekerjaan, perbedaan promosi, prospek karir, kekerasan seksual verbal tidak berpengaruh nyata terhadap tingkat kepuasan kerja.

Kepuasan kerja memiliki kaitan dengan tingkatan harapan yang dimiliki individu dengan pekerjaan yang dimilikinya. Paradoks ketidakadilan gender dan kepuasan kerja dapat terjadi karena beberapa hal. Kesempatan kerja di Provinsi DI. Yogyakarta termasuk dalam kategori rendah, dapat memiliki pekerjaan yang dekat dengan rumah dan keluarga merupakan salah satu hal yang di syukuri oleh karyawan. Karyawan juga seringkali dimotivasi untuk bekerja dengan ikhlas, bekerja sebagai ibadah, harapan yang akurat sesuai dengan harapan mereka

Menurut Bender et al. (2005) kayawan khususnya perempuan mungkin disosialisasikan untuk mengantisipasi seberapa besar kepuasan yang dapat mereka peroleh dari pekerjaan dan tidak terkejut dengan apa yang mereka peroleh di dalam kenyataan. Menurut Celik
(1997) tingginya kepuasan kerja meskipun terjadi ketidakadilan gender merupakan hasil dari posisi karyawan (khususnya perempuan) yang rendah di dunia kerja. Hal ini dikarenakan kepuasan merupakan fungsi dari harapan, dan jika wanita memiliki harapan yang lebih rendah tentang hasil pasar tenaga kerja, harapan mereka lebih mudah dipenuhi.

\section{KESIMPULAN DAN SARAN}

\section{Kesimpulan}

1. Perusahaan didominasi oleh karyawan laki-laki dengan karakterisktik sebagian besar karyawan laki-laki berada pada usia 43-54 tahun, memiliki masa kerja lebih dari 20 tahun, tingkat pendapatan Rp 1.000.000 - Rp 2.000.000, berpendidikan terakhir SMA dan sudah menikah. Sedangkan karakteristik karyawan perempuan sebagian besar berusia muda (21-31 tahun), memiliki masa kerja rendah (1-3 tahun), mendapatkan gaji $\mathrm{Rp} 1.000 .000$ Rp 2.000.000 per bulan, memiliki jenjang pendidikan sarjana, dan sudah menikah.

Selain komunikasi marginalisasi yang diterima oleh karyawan dengan proporsi yang sama antara laki-laki dan perempuan, komunikasi stereotipi, diskriminasi, subordinasi dan kekerasan seksual diterima oleh karyawan laki-laki dan perempuan dalam proporsi yang berbeda. 
Laki-laki dan perempuan memiliki kepuasan kerja yang relatif sama kecuali pada kepuasan terhadap gaji dan kondisi kerja.

2. Secara umum, tidak cukup bukti untuk menyatakan bahwa karakteristik individu tertentu berhubungan dengan intensitas komunikasi gender yang akan diterimanya. Namun, hasil uji menunjukkan bahwa stereotipi yang tinggi sejalan dengan rendahnya tingkat pendidikan dan tingkat penghasilan, serta kekerasan gender yang tinggi sejalan dengan pendeknya masa kerja seorang karyawan.

3. Komunikasi gender tidak memiliki hubungan yang kuat dengan kepuasan kerja karyawan. Pengalaman negatif di dunia kerja tidak berhubungan nyata terhadap tingkat kepuasan kerja. Terdapat hubungan yang melemahkan hipotesis, seperti stereotipi yang berhubungan nyata positif dengan kondisi kerja dan status, serta kekerasan gender yang berhubungan nyata positif dengan kondisi kerja. Karyawan yang mendapat terpaan komunikasi gender tinggi seperti, karyawan perempuan, karyawan laki-laki dengan pendidikan rendah, karyawan dengan penghasilan rendah, serta karyawan baru dengan masa kerja pendek memiliki harapan yang rendah terhadap pekerjaannya, sehingga walaupun mendapat perlakuan bias gender, karyawan tersebut tetap bersyukur dan memiliki kepuasan kerja yang relatif sama dengan karyawan lainnya.

\section{Saran}

Kesetaraan gender merupakan satu dari beberapa tujuan MDGs yang tidak tercapai secara optimal sampai tahun 2015, dan menjaditujuan kelima yang ingin dalam SDGs. Berdasarkan simpulan penelitian, dalam upaya mencapai kesetaraan gender, peneliti memberikan saran kepada seluruh pihak terkait untuk:

1. Memberikan pemahaman gender kepada pelaku usaha, karena tidak semua perusahaan memahami tentang gender.

2. Menciptakan pemahaman karyawan perusahaan mengenai gender, konsep diri, sikap, kemampuan sesungguhnya yang dimiliki perempuan maupun lakilaki serta prestasi yang sebenarnya mampu dicapai perempuan dan laki-laki dalam mewujudkan kesetaraan gender.

\section{DAFTAR PUSTAKA}

Aydin A, Uysal S, Sarier Y. 2012. The effect of gender on job satisfaction of teachers: a meta-analysis Study. Social and Behavioral Sciences 46: $356-362$

[BAPPENAS] Badan Perencanaan Pembangunan Nasional. 2012. Indeks kesetaraan dan keadilan gender (IKKG) dan indikator kelembagaan pengarusutamaan gender (IKPUG): kajian awal. Jakarta (ID) : Direktorat Kependudukan, Pemberdayaan Perempuan, dan Perlindungan Anak, Kedeputian Bidang Sumber Daya Manusia dan Kebudayaan BAPPENAS

Barret M. dan Davidson M.J. 2006. Gender and communication at work. Inggris: Ashgate Publishing Limited 
Bender KA, Doonohuey SM, Heywood JS. 2012. Job satisfaction and gender segregation. Oxford Economic Paper 57:479-496. doi:10.1093/oep/gpi015

Bilkis A., Habib S.B., Sharmin T. 2010. A review of discrimination in employment and workplace. ASA Unv Rev 4(2):137-150

[BPS] Badan Pusat Statistik. 2014. Keadaan Angkatan Kerja Daerah Istimewa Yogyakarta, Agustus 2014. Katalog BPS: 2301003.34. Yogyakarta: BPS D.I Yogyakarta

[BPS] Badan Pusat Statistik. 2015. Tingkat Penganguran Terbuka Penduduk Berumur 15 Tahun ke Atas menurut Kelompok Umur dan Jenis Kelamin, 2009-2012. [internet] dapat diunduh di http://www.bps.go.id/websit e/tabelExcelIndo/indo_40 7. $\underline{\mathbf{x l s}}$

Celik M. 2011. A theoritical approach to the job satisfaction. Polish $J$ of Managem Stud 4: 7-15

Ciarnaine R, Kumpikaite V, Vienaziendiene M. 2010. Expectations And Job Satisfaction: Theoritical and Empirical Approach. 6th International Scientific Conference May 13-14, 2010, Vilnius, Lithuania BUSINESS AND MANAGEMENT 2010 Selected papers. Vilnius, 2010. ISSN 2029-4441 print / ISSN 2029-428X CD doi:10.3846/bm.2010.131

http://www.vgtu.lt/en/editions /proceedings

Clark AE. 1997. Job satisfaction and gender: why are women so happy at work. Labour Economic 4:341-372

Gil-Gonzalez D, Vives-Cases C., Borrell C, Agudelo-Suarez AA, Dardet A. 2013. Social determinants of self-perceived discrimination in Spain. $J$ of Public Health 127:223-230

Guay S, Goncalves J, Jarvis J. 2014. Verbal violence in the workplace according to victim' sex-a systematic review of the literature. Aggression and Violent Behavior 19:572-578

Gumbang B, Suki NM, Suki NM. 2010. Differences between job satisfaction, organisational commitment and gender. $L J$ of Muamalat and Society, Vol. 4, 2010, pp. 1-13

Hubeis AVS. 2010. Pemberdayaan Perempuan dari Masa ke Masa. Bogor (ID): IPB Press

[ILO] International Labour Organization. 2015. Menilai Pekerjaan Layak di Indonesia: Sekilas tentang Profil Nassional untuk Pekerjaan Layak. Indonesia: ILO [internet] dapat di unduh di http://www.ilo.org/wcmsp5/g roups/public/---dgreports/--integration/documents/public ation/wcms_186206.pdf

Kifle T dan Desta IH. 2012. Gender differences in domains of job satisfaction: evidence from doctoral graduates from Australian universities. Economic Analysis and Policy 42(3):319-338

Maume DJ. 2011. Meet the new boss, same as the old boss? Female supervisors and subordinate career prospects. Social Science Research 40:287-298 
Negi N. 2009. Gender, Race, Job Satisfaction And The Social Services. The Intl $J$ of Continuing Soc Work Educ 12 (1):18-26

Popa OR dan Bucur NF. 2014. Gender discrimination and education practitioners. Reality, perception, possible solutions. Soc and Behav Scien 127: 459 - 463

Pujisari Y. 2010. Pengaruh Peran Gender terhadap Kepuasan Kerja, Stress Kerja dan Keinginan Berpindah. Jurnal Solusi 5(2):1-16

Rutherford S. 2011. Women's work, men's cultures: overcoming resistance and changing organizational cultures. London: Palgrave Macmilan
Juli 2016 Vol 14, No 2

Sabharwal M dan Corley E.A. 2009. Faculty job satisfaction across gender and discipline. The Social Science Journal 46:539-556

Turturean C.I., Chirila C., Chirila V. 2013. Gender discrimination on the Romanian labor market-myth or reality?. Soc and Behavioral Sciences. 92:960-967

Venny A. 2010. Editor : Agung Wasono Jakarta: Kemitraan bagi Pembaruan Tata Pemerintahan di Indonesia

Wood JT. 2001. Gendered Lives: Communication, Gender, and Culture. United States of America: Wadsworth Thomson Learning 